\title{
Female migrants are «dreaming»: The future wishes of themselves and their children
}

Pelin Karakuş-Akalın, İstinye University, Department of Psychology, Istanbul, Turkey Melek Goregenli, Izmir Solidarity Academy, Izmir, Turkey

Introduction

The issue of gender has received considerable critical attention in the study of migration especially in the past two decades Thus, gender specific examinations showed that impacts of migration on women and men differs and especially the female migrants with a low level education and income become one the most vulnerable groups.

A number of studies investigating the impact of intra-country migration on women's life in Turkey reported that the factors contributing to the movement are seeking job opportunities for oneself and one's family members, searching for a better life and supporting their children, marriage, family reunification and safety concerns (e.g. Göregenli et al., 2015; 2016) which all can be concerned as the tendencies of promoting well-being in personal and family context. Unfortunately, migrant women mostly do not experience the circumstances that they expect in the receiving society. It has been demonstrated that migration brings new challenges exposing women to frailities resulting from working in less-skilled, undocumented jobs, lack of social security, gender based discrimination in labour market, social isolation and acculturative stress etc. On the other hand migration impact women's lives in an empowering way by providing new opportunities as a source of income, autonomy, self-confidence, changing gender rolesin support of women's rights. The main question addressed in this paper is: How the wishes of female migrants for oneself and for their children related with their migration experiences and gender relations?

Method

Semi-structured interviews were conducted with 41 ethnically different intra-country female migrants resettled in a metropolitan province of Izmir, in Turkey.

The interview form included several sociodemographic questions (e.g. age, income level, ethnic identity), open-ended questions related to migration history and the changes in cultural practices and gender roles. The taped interviews were transcribed and analysed by the thematic content analysis.

\section{Results}

The findings revealed that three major themes emerged related to participant's wishes about their own future: 1. To have a property (e.g. buying a house) 2. Return migration 3. To have a profession and economic freedom (See Table 1). Concerning their children, the dominant wishes were related with the hope of better educational or wealthy opportunities to their children, wishes for their children to acquire a profession to live self-sufficiently and a good spouse to get married (See Table 2).

\begin{tabular}{|c|c|c|}
\hline Themes & Fre. & $\%$ \\
\hline Have of property & 14 & 18,2 \\
\hline Return migration & 9 & 11,7 \\
\hline Have a profession & 8 & 10,4 \\
\hline Travelling & 7 & 9,1 \\
\hline Being with beloved ones & 7 & 9,1 \\
\hline Country life & 7 & 9,1 \\
\hline I am pleased, no wishes & 6 & 7,8 \\
\hline Being healthy & 5 & 6,5 \\
\hline Not to work & 4 & 5,2 \\
\hline Freedom & 4 & 5,2 \\
\hline Good human relations & 3 & 3,9 \\
\hline Make a pilgrimage & 2 & 2,6 \\
\hline Helping others & 1 & 1,3 \\
\hline Total| & 77 & 100 \\
\hline
\end{tabular}

\begin{tabular}{|c|c|c|}
\hline Themes & Fre. & $\%$ \\
\hline $\begin{array}{l}\text { To provide better educational } \\
\text { opportunities }\end{array}$ & 10 & 15,2 \\
\hline $\begin{array}{l}\text { Have a profession to live self- } \\
\text { sufficiently }\end{array}$ & 9 & 13,6 \\
\hline Have a good spouse & 9 & 13,6 \\
\hline Live on welfare & 9 & 13,6 \\
\hline Have a property & 7 & 10,6 \\
\hline Family unity & 6 & 9,1 \\
\hline Happiness-Tranquility & 6 & 9,1 \\
\hline Health & 3 & 4,5 \\
\hline d dont know, they decide & 3 & 4,5 \\
\hline Freedom & 2 & 3,0 \\
\hline I provided everything & 1 & 1,5 \\
\hline Live in a little town & 1 & 1,5 \\
\hline Total & 66 & 100,0 \\
\hline
\end{tabular}

\section{Discussion}

It is apparent from the findings that the wishes of female migrants are closely related with their migration experiences and gender relations.

In detail, the desire for buying a house for oneself may be explained by a challenging motivation in order to cope with deprivative outcomes of migration. Moreover it may be a sign of an integration strategy with host society during the acculturation process. In a similar vein, return migration could be attributed to the separative or marginalized way of acculturation (Berry, 1997).

The desires related to have a profession, travelling, not to work and freedom accord with the oppressive gender roles in family life which supports previous research (e.g. Göregenli, et al. 2015).
The wishes about being with beloved ones and good human relations for oneself and have a good spouse and family unity for their children can be explained by the collectivistic tendencies (Triandis, 1995).

These findings further suggest a strong link may exist between the wishes of female immigrants and basic human values (Schwartz, 1994).For instance, a desire for a propoerty for oneself or desires for better educational opportunities and life conditions may be result of a need for power, achievement or security whereas freedom, not to work, travelling can be explained by stimulation and self-direction.

\section{Conclusion}

This study is strongly encouraging further qualitative and quantitative works to study wishes and expectations of female migrants in relation to gender ideology, human values, individualism-collectivism and acculturation attitudes within cultural and cross-cultural contexts. Thus, targetted policy interventions can be developed in order to foster resilience and life satisfaction of female immigrants by making their dreams come true.

References:

acculturation, adaptation Applied Psychology, 46, 5-34.

Goregenli, M., Karakus, P. and Gokten, C. (2016). Acculturation attitudes and urban-related identity in three largest cities of Turkey. Migration Letters, 13, 413-428.

Göregenli, M., Umuroglu, I. G. and Karakus, P. (2015). Gende differences in spatial and cultural integration: Interna Conference: Gender, Culture \& Migration, 6-7 March, Poland. Schwartz, S. H. (1994). Are there universal aspects in the content and structure of values? Journal of Social Issues, 50 , 19-45.

Triandis, H. C. (1995). Individualism and Collectivism. Westview Press. 